\title{
PESANTREN AND THE FREEDOM OF THINKING: Study of Ma'had Aly Pesantren Sukorejo Situbondo, East Java, Indonesia
}

\author{
Hatim Gazali \& Abd. Malik \\ Center for Religious and Cross Cultural Studies (CRCS) Gadjah Mada \\ University, Yogyakarta, Indonesia
}

\begin{abstract}
Various studies on Pesantren have been conducted through various lenses and perspectives; however, its attractiveness is still there. In some points, the pesantren is well known as a conservative institution in which freedom of thinking is limited. This article is willing to show that not all pesantrens limit their students' freedom of thinking. One of them is Ma'bad Aly (higher education), one of the education institution in Pesantren Salafiyah Syafizyah Sukorejo Situbondo which focuses its teaching on fiqh. Fiqh, or Islamic jurisprudence, is one of the branches of Islamic science. In some pesantrens, the teaching of figh is limited to one school or madhhab, particularly school of Shafiti. However, in Ma'bad Aly, not only one school of thought is taught, but figh of four schools of thought. It shows a bigh tolerance and respect for differences. In order to seek a new ingredient in formulating Islamic law, the teaching of fiqh is combined with other sciences such as philosophy, sociology, and anthropology. This new ingredient produces a rich discourse of figh and widens its scope of discussion to include to religious relationships, gender, buman rights, ecology, and other contemporary issues such as interfaith marriage, the possibility of a non-Muslim being president, and the role of women in the public sphere. Looking from the curriculum, the method of teaching, and the publication of bulletin of Tanwirul Afkar, this article proves that freedom of thinking is well-maintained at Ma'bad Aly.
\end{abstract}


Key Words: Ma`had Aly, freedom of thinking, and pesantren.

\section{A. Introduction}

\section{.... Aneh, mengapa berpikir hendak dibatasi. \\ Apakah tuban takut terhadap rasio yang diciptakan oleb tuhan sendiri? Saya percaya pada tuhan, tapi tuhan bukanlah daerah terlarang bagi pemikiran. Tuhan ada bukan untuk tidak dipikirkan adanya, tuhan bersifat wujud bukan kebal dari sorotan kritik. Sesunggubnya orang yang mengaku bertuban tapi menolak berpikir bebas, berarti menghina rasionalitas eksistensinya Tuhan.... ${ }^{1}$}

Some researchers and scholars look at pesantrens (Islamic boarding school) as backward education institutions in which there is only the study of classic texts of Islamic resources, like kitab kuning ${ }^{2}$ ("yellow books"), and students wear sarung, ${ }^{3}$ and so pesantrens are for the traditionalist. ${ }^{4}$ The pesantren is usually led by a kiai (Muslim boarding school cleric), assisted by a number of his senior santri $i^{5}$ or family members. The pesantren is an important part of the kiais life, as a medium to expand his preaching and influence through his teaching. Some observers, like Martin Van Bruinessen, say that the pesantren is a unique education institution that has deep roots in Indonesian tradition. As a traditional institution, usually found in small villages, pesantren surely

1 Ahmad Wahib, Pergolakan Pemikiran Muslim (Jakarta: LP3ES, 2003), p. 23

2 Kitab kuning is Islamic book that is yellow in color and usually from the Middle East. Martin van Bruinessen, "Pesantren and Kitab Kuning: Maintenance and Continuation of a Tradition of Religious Learning”, in: Wolfgang Marschall (ed.), Texts from the Islands: Oral and Written Traditions of Indonesia and the Malay World (Berne: University of Berne, 1994), p. 121.

3 Sarung is dress code in Indonesia, which many santris use it.

${ }_{4}$ The distinction between traditionalist and modernist reveals a confused meaning. However, these terms have been accepted to show the Nahdlatul Ulama as traditionalist and the Muhammadiyah as modernist. These distinctions are based on different views of Islam. However, some modernists recently also build pesantren.

5 Santri(s) are the students of a pesantren. This category differs from Geertz's term when he researched Muslim in Java. 
have made a great contribution to empowering civil society ${ }^{6}$ by helping the poor get education and guiding the religious understanding of society. ${ }^{7}$

The pesantren is the oldest Islamic education institution in Indonesia. The pesantren, therefore, has had a great involvement in empowering Indonesians' education. However, besides being an old institution of Islamic mission ( $\left.d a^{6} w a\right)$, the pesantren is also well known as a conservative institution in which freedom of thinking is limited. The basic reason for this is to save Muslims from a wrong understanding of Islam that leads to becoming an infidel. Because of this, some Muslim scholars proclaimed the close of ijtihad (qafl bäb al-ijtihāad).

Furthermore, the image of pesantrens nowadays is very negative. The various terrorist bombings in Indonesia are committed by people graduated from pesantrens. Ali Imran, Ali Ghufron, and Amrozi, the Bali bombers, are from the pesantren of Al-Islam, Lamongan. In addition, Abu Bakar Ba'asyir, the allegedly leader of Jamaah Islamiyyah, which is claimed to be a terorist organization, is leader of Pesantren al-Mukmin Ngruki, Solo, Central Java. ${ }^{8}$ Because of this, realizing that the majority

${ }^{6}$ In Indonesia, the term of civil society is well known, at least, as (1) masyarakat sipil; one of the books using this term is Mansour Fakih's Masyarakat Sipil untuk Transformasi Sosial: Pergolakan Ideologi LSM Indonesia, (Yogyakarta: Pustaka Pelajar, 1995); (2) "masyarakat kewargaan/warga", a term coming from AIPI (Asosiasi Ilmu Politik Indonesia, Indonesian Politics Association); and (3) "masyarakat madanı"; a term used firstly by Anwar Ibrahim, former Prime Minister of Malaysia, and then Nurcholish Madjid disseminates this term in his article, "Menuju Masyarakat Madani”, Ulumul Qur'an (No. 2 VII/1996).

7 M. Syafi'i Anwar describes three perspectives: theological, historical, and sociological. In the theological perspective, pesantren contributes pluralism and multiculturalism views such as the using of different genres of kitab kuning. In the historical one, pesantren is the oldest Islamic education institution, and made a great contribution to Indonesian independence. And, in the sociological one, pesantren is an agent of social change. M. Syafi'i Anwar, "Uncovering the Wisdom of Pesantren for Multiculturalism”, ICIP Journal, Vol. 4, (No. 1, June 2007), p. 1-2.

8 Syarif Hidayatullah has research on three pesantrens, al-Mukmin Ngruki, alIslam Lamongan, Ihyaussunnah Yogyakarta, entitled "Pesantren and Religious Radicalism", presented in the seminar of Gadjah Mada University Research Cluster for GMU's $57^{\text {th }}$ Anniversarry, conducted by the office of Deputy Rector for Research and Community Service on November 28, 2006 in Yogyakarta. 
of terrorists were pesantren alumni, after the second Bali incident on October 1, 2005, Vice President of Indonesia, Jusuf Kalla, announced that the government was planning to monitor the activities of the pesantrens. This has provoked many responses, especially from religious leaders, either pro or contra, about this controversial decision. Some of them think that this plan is a clear indication of the government's intervention in pesantrens. At the same time, some people also consider the fact that the majority of terrorists graduated from pesantrens.

One of the reasons for bombing is an interpretation of the Qur'an. The textual interpretation of the Qur'an, to some extent, leads someone to be a terrorist. The doctrine of jibad, for instance, is often used to legitimate the bombings and suicide. One meaning of jibad is holy war (al-qità $)$. However, it has many other meanings. Terrorists and fundamentalists ${ }^{9}$ deny the freedom of thinking in interpretating the Qur'an. As well, Pesantren al-Mukmin Ngruki denies the freedom of thinking.

Observing this kind of pesantren, like al-Mukmin, denying terrorists freedom of thinking, and the issue of the close of the ijtihäd, I would like to research one pesantren in East Java, Situbondo, as an example of a pesantren that promotes freedom of thinking. As a specific subject, I will focus on one institution in that pesantren, namely Ma'had Aly. When we observe the curriculum, method of teaching, and its weekly bulletin, Tanwirul Afkar, we will find how this institution promotes freedom of thinking.

\section{B. Pesantren: its Characteristic and Typology}

Nowadays, there are many pesantrens developed in Indonesia, not only in Java but around this country. Pesantren doesn't only indicate an education institution for the traditionalist, since the modernist now also builds pesantren. Some observers, like Martin van Bruinessen, say that the pesantren is a unique education institution that has deep roots in Indonesia tradition. For that reason, the pesantren can be called a typical

9 There is no single meaning of fundamentalism. Bassam Tibi states that fundamentalism is more than extrimism and terorism; Bassam Tibi, Ancaman Fundamentalisme, Rajutan Islâm Politik dan Kekacauan Dunia Baru, trans. Imron Rosyidi, et.all., (Yogyakarta: Tiara Wacana, 2000), p. xii. 
education institution in Indonesia, because in some aspects, pesantrens are different from other traditional institutions in the Islamic world. However, on the other hand, pesantrens have an international orientation with Mecca as its central orientation. ${ }^{10}$ This consideration is based on the fact that some pesantrens imported many classic Islamic books from Mecca and other countries in Middle East to be the main source of its teaching. Moreover, those books, called kitab kuning, ${ }^{11}$ have been accepted as legitimate sources of teaching in pesantrens.

The main purpose of a pesantren, as Bruinessen explains, is:

.... the transmission of traditional Islam as laid down in scripture, i.e., classical texts of the various Islamic disciplines, together with commentaries, glosses and super commentaries on these basic texts written over the ages. These works are collectively known, in Indonesia, as kitab kuning, "yellow books", and a name that they owe to the tinted paper on which the first Middle Eastern editions reaching Indonesia were printed. ${ }^{12}$

In a pesantren, the truth of kitab kuning is regarded as absolute knowledge and untouchable; it can only be explained and commented on. All truths in those kitab kuning have been accepted as final knowledge that cannot be changed in whatever context. There have been many efforts from later ulama to reinterpret the tradition, but these works cannot pretend to offer more than summaries, explications or rearrangements of the same. Even radical [re]interpretations of the classical texts are not acceptable.

For that reason, modernists and reformists refuse the kitab kuning and prefer to directly interpret the Qur'an and hadith as the main sources of Islamic knowledge. Modernists state that the gateway is still open. On the contrary, for traditionalists, the gateway of interpretation is closed and they can only refer religious matter to kitab kuning. Therefore, the

${ }^{10}$ Martin van Bruinessen, Kitab Kuning, Pesantren, dan Tarekat: Tradisi-tradisi Islam di Indonesia (Bandung: Mizan, 1999), p. 21.

${ }^{11}$ A deeper observation about this subject can be read in Bruinessen's books.

${ }^{12}$ Martin van Bruinessen, "Pesantren and Kitab Kuning: Maintenance and Continuation of a Tradition of Religious Learning", in Wolfgang Marschall (ed.), Texts from the Islands: Oral and Written Traditions of Indonesia and the Malay World, (Berne: University of Berne, 1994), p. 121. 
tradition of the pesantren cannot be separated from kitab kuning, an important element within it.

As an Islamic educational institution, pesantrens taking on a role in spreading and empowering Islamic society has a long history. Pesantrens are usually run by a kiai, assisted by a number of his senior santri or family members. The pesantren is an important part of the kiais life, as a medium through which he expands his preaching and influence by his teaching. Therefore, kiai becomes a central power as well as the owner of the institution.

In the pesantren system, there are several interconnected elements. The first is the kiai, the main factor through whom the pesantren system is established. He is the person who underpins the system. Secondly, there are the santris, which are the students who learn Islamic knowledge from the kiai. The third element is the pondok, a dormitory system provided by the kiai to accommodate his students. A pondok is usually a simple form of accommodation and has few facilities. The pondok usually consists of shared rooms, with one room being occupied by five to ten santris. The pesantren, therefore, is comprised of a housing complex, which includes the houses of the kiai and his family, some pondoks, and teaching buildings, including a mosque. The fourth element of the pesantren is the lesson material or commonly called kitab kuning, as mentioned above. By these characteristics, pesantren emerged as typical education institutions in Indonesia.

The other uniqueness of the pesantren traditon is its system of learning. As explored by Zamakhsyari Dhofier (1982), the pesantren usually uses a traditional system of learning. There are various techniques of teaching, but the most commonly used are bandongan and sorogan. Sorogan is a kind of religious teaching in pesantren that is conducted by either the kiai or his senior santri (ustad»). Many santri attend a mosque to listen to the reading of kitab kuning conveyed by the kiai. Santri attendance does not depend on either their level of knowledge or their age. The system doesn't recognize stages, or hierarchies, or classes. Although many pesantren have recently adopted the modern system with classes and stages of curricula, the oldest system is still used in some pesantren.

Some observer said that the pesantren is an education institution that is difficult to change. In some aspects, that assertion may be true 
because the pesantren community consider kitab kuning as a reliable source that cannot be changed. Santri and kyai accept the content of kitab kuning as an infallible source to reach religious knowledge that is suitable for a long time. But at the same time, the pesantren doesn't maintain a strictly exclusive view. It can be seen that pesantren are capable of accommodating and adopting local culture and tradition. ${ }^{13}$ Pesantren, then, can combine Islamic thought with local knowledge. This acceptance shows its characteristic as a moderate and tolerant institution. In another aspect, this accommodation teaches santri to be tolerant of diversity.

According to Abasri, ${ }^{14}$ there are three types of pesantren. First, there is the traditional pesantren which still maintains traditional values, without prominent inovation. This kind of pesantren usually still exists in villages and isolated areas. Second, there is the post-traditional pesantren. The character of this pesantren, on one hand, has adopted the modern education system, while on the other hand still maintains some characteristics of the traditional pesantren. The method of teaching in this kind of pesantren is modern, but still uses kitab kuning. Third, there is the modern pesantren. This kind of pesantren has significantly changed both the education systems and structure of the pesantren.

Following this typology, in Pesantren Salafiyah Syafii'yah Sukorejo, Ma'had Aly has built a traditional pesantren. The term 'Salafiyah' refers to traditional, in contrast to khalafiyah. However, observing the several institutions found in pesantrens, this pesantren is modern, because this pesantren not only teaches Islamic studies but also modern sciences. This pesantren runs a university (IAII, Insitute Agama Islam Ibrahimy, Akademi Kelauatan), and school, from elementary school to senior high school. The references which are used in this pesantren are not only kitab kuning

${ }^{13}$ For the modernist, this accommodation will be called a heterodox action or bid'ah. Like Muhammadiyah, reformist groups tend to purify Islam from local beliefs. On the contrary, pesantrens still maintain local culture and collaborate with Islamic teaching. This collaboration can be seen in the ritual of, for instance, tablilan that illustrates the belief of Javanese people about spirit after death.

${ }^{14}$ Abasri, "Sejarah dan Dinamika Lembaga-lembaga Pendidikan Islam di Nusantara: Surau, Meunasah, Pesantren, dan Madrasah", in Samsul Nizar (ed.), Sejarah Pendidikan Islam: Menelusuri Jejak Sejarah Pendidikan Islam Era Rasulullah sampai Indonesia (Jakarta: Prenada Media Group, 2007), p. 289-90. 
but also several other references, as well as other modern institutions.

\section{Islamic View on Freedom of Thinking}

God reveals all religion to human beings as homo sapiens (albayawān al-nätiq), not to animals. This is because human beings have reason which can interpret God's revelation. This is the excess of human being rather than others. The Holy book that was revealed many years ago in a certain context is impossible to understand by human beings without reasoning toward it. How can the Qur'an answer and solve contemporary problems, when the Qur'an did not discuss it?

Since religion (the Qur'an came to homo sapiens, it means that God wishes His verses to be read, understood and interpreted. Therefore, reason has an important position in Islam. Even, Fakhruddin Al-Razi in Mafatih al-Ghayb stated: ${ }^{15}$

How can al-'aql be God's apostle to His creation; if there is no reason ( $\left.a l^{\prime} a q\right)$, so the rule will not be arranged. Reason is the real apostle.

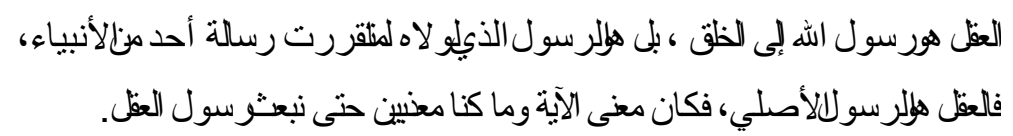

This statement clearly shows how important reason is. Therefore, without reason, religion is useless. It is important that this statement is interpretation of the Qur'an surat 16:36; "And certainly We raised in every nation an apostle saying: Serve Allah and shun the Shaitan. So there were some of them whom Allah guided and there were others against whom error was due; therefore travel in the land, then see what was the.end of the rejecters."

Moreover, in the methodology of Islamic jurisprudence (usü alfiqh) of Imām Mălik, reason has the competence to - borrowing Imam Syafi'i's term - takbsisis (make more specific) the Qur'an (takbșis bil'-'aql). In Fasl al-Maqäl fi-mà bayna'l-Hikmah wa'l-Shari' ah mina'l-Ittișäl, Ibn Rushd stated: "if someday there is a doctrine contradicting human reason, the doctrine has to be reviewed by the method of ta'mil'. Therefore, all

${ }^{15}$ Fakhruddin Al-Razi, Mafātị̣ al-Ghayb, (Beirut: Dār al-Fikr, 1993), juz x, p. 175. 
doctrines of religion must be rational and reasonable. Surely, some aspects of religion that are irrational are "taken for granted", such as why Muslims must do salàt.

Mentioned by God, the Qur'an is the book of guidelines (2:185, 6:71, 7:52, 16;89) for all creation. As a guideline, the Qur'an surely did not mention everything in detail. For instance, justice must be struggled for, but it did not mention the model, form of justice. For details, Allah utterly believes in human beings to interpret it. This can be read from the pronouncement of the Qur'an in repeatedly questioning, 'are you witless', 'do you not understand?', etc. For that reason, reason became the guidance for God's revelation in order to seek and determine everything specifically.

Muslims believe that God's revelation stopped, while the situation is always changing, uncontrolled by religion. If God's revelation is interpreted literally, definitely it will not be significant anymore. It is the duty of human beings, as khitäb (object) of the Qur'an, to contextualize the Qur'an in contemporary society. Detailed rules which are ordered by the Qur'an must be arranged by human beings.

The mandate of human beings as a khalifah (caliphate) reinforce human beings as responsible to the Qur'an, whether it is interpreted literally, with the consequences of the loss of contextual meaning, or contextually. If we choose the method of literal interpretation, we surely "kill" the Qur'ān, because the Qur'ān came in a certain era (prophetic era), meanwhile the situation and conditions have changed. Therefore, in order to keep the meaning of the Qur'an, we have to choose contextual interpretation. Doing this interpretation is, I think, the meaning of the

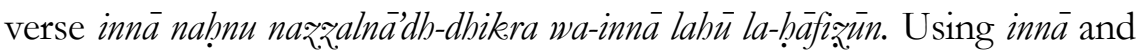
nabnu indicates the involvement of human beings in keeping the Qur'an. Meanwhile, the term of la-hâfizun is not only keeping the text of the Qur'an but also its meaning and significance.

One of the reasons why we have to choose the contextual interpretation is that in interpreting the Qur'an, the readers (human beings) have authority to interpret it. 'A $\mathrm{Ii}$ b. Abi Ṭalib stated that the Qur'an is not talking, but the reader speaks it (al-Qur'an bayna daffatay almuṣhaf, là yanțiqu, wa-innamā yatakallamu bibi'r-rijāl). Therefore, the interpretation of the Qur'an is valid as long as it follows the rules of 
interpretation (qawäid al-tafsir) and universal values such as humanity, justice and benefit (maslahah). Due to the freedom of thinking, there are many tafsirs which are different from one to another.

\section{Ma'had Aly and the Atmosphere of Freedom of Thinking}

Ma'had Aly is one of the education institutions in the Pesantren Salafiyah Syafi'iyah Sukorejo Situbondo ${ }^{16}$ whose teaching focuses on fiqh. Not all santris in the pesantren can study in this institution. Santri who want to study in this institution must do exercises till they are considered qualified and reliable to study in the institution. The very strict recruitment shows that the institution tends to create professional and expert students of fiqh. For this reason, the institution is called ma'bad 'aly, a "higher institution".

Ma'had Aly was established in 1989 when K.H. As'ad, the founder of Pondok Pesantren Salafiyah Syafi'iyah, and some ulama realized the lack of experts of figh in many pesantrens. This condition motivated K.H As'ad and the others to establish an institution concerned with fiqh. Fiqh as an approach became a unique characteristic of the institution in which students use fiqh as an approach to see the complexity of reality. Is it possible?

Figh, or Islamic jurisprudence, is one of the branches of Islamic science. For a long time, figh has been a great science and dominant in Islam. It is not surprising because, as Bruinessen describes, figh determines concrete implications for daily life for Muslims, as individuals or as a group. ${ }^{17}$ Its study encompasses all practical dimensions of Islam, including how to pray well, fast, go on pilgrimage, trade, be in debt, have a good attitude to others, etc. However, classic figh on how to face

${ }^{16}$ Salafiyah Syafi'iyah is the name of the pesantren, but it is also known as pondok pesantren Sukorejo, referring to the name of village where it is established. The pesantren is located in Sukorejo, Situbondo, East Java. The founder of the pesantren was K.H Samsul Arifin, Maduraness people, who migrated from Madura to Situbondo. After his death, the leader of the pesanrten was his son, KH As'ad Syamsul Arifin, known as one of the popular ulama from the Nahdlatul Ulama. Today, the pesantren is led by K.H. Fawaid As'ad, the third leader. The data on pesantren Sukorejo and Ma'had Alyin this paper is drawn from the book Pedoman Santri Baru Pesantren Salafiyah Syafi'iyah Sukorejo Situbondo (Situbondo: As-syarif Press, 1999 ).

${ }^{17}$ Martin van Bruinessen, Kitab Kuning, p. 112. 
other people with a different religion and belief is seldom found. Classic figh used in many pesantrens only cover observance ('ubüdiyyah) and social matters (mu'amalab).

Nevertheless, Ma'had Aly uses fiqh as the central aim and approach to face any problem in society. In some pesantrens, the teaching of figh is limited to one ulama school or madhbab. The popular madbhab is Shafi'ite. Unusually, in Ma'had Aly, fiqh reference books are not trapped in one of these schools of thought. Kitäb al-Figh 'alā Madhähib al-Arba'ab (Fiqh of Four Schools of Thought) is used to broaden perspectives. This acceptance actually contains clear signs of high tolerance and respect for differences that occur between the four schools of thought. For this, Ma'had Aly gives the sage words of the prophet of Islam who repeatedly told us all "ikhtilaf al-a'immah rahmah, the difference between leaders is a mercy."

Bruinessen describes the preference of kitab kuning or classical text in pesantrens as unchangeable. This means that for a long time pesantrens have only learned and repeated the same texts. Bruinessen arranged systematically the reference texts of figh used in pesantrens, such as Taqrib, I'änat al-Ṭälibin, Fath al-Qarib, Kifāyat al-Akbyär, al-Iqnā', Bajūì, and others. All of these books are classic books that were created about 15 century ago. Of course, the area covered by those books was limited to only 'ubuidiyyah and mu'amalah and there is very little explanation about religious relationships. Because those books were arranged and produced long ago, some ulama in Indonesia are trapped in literal interpretation. They use kitab kuning as the sole basis for deciding the rule and law for recent times without considering the context of when these books were produced.

Unlike the description of pesantrens found in Bruinessen, however, Ma'had Aly provides some new reference texts and these are not only limited to Islamic books. In its library, there are many books related to other sciences, like philosophy, sociology, and anthropology. This means that Ma'had Aly tends to seek a new ingredient in formulating Islamic law. Combining figh with other sciences has produced a rich figh discourse, interacting with social problems, that cannot be found in other pesantrens and classic texts. As we will see in its bulletin, Ma'had Aly expands its figh to include the widest domain of social matters include religious relationships, gender, human rights, ecology and other contemporary 
issues.

In 2002, Ma'had Aly was legalized by the Ministry of Religious Affairs as having an equal degree status with the Masters program in a university. Students who graduate from this institution get an MHI (Master Hukum Islam or Masters in Islamic Law). This equality establishes Ma'had Aly as a modern education institution operating within a traditional pesantren.

\section{Curriculum}

The education implemented at Ma'had Aly is based on a curriculum which is compatible with the program of Fiqh-Usül Fiqh. Therefore, the core courses are comparative fiqh (worship, politics, criminal, civil, and mu'ämalab), 'Ulümu al-Qur'àn, Tafsir al-Aḅkàm, 'Ulüm al-Hadith and Hadith Aḅkàm, Tärikh al-Tashri wa'l-Qada', Hikmat al-Tashri wa-Falsafatuh, the History of Madhäbib al-Fiqh, al-Masäil Fiqhiyyah, the philosophy of Islamic law, research methodology of Islamic law, al-Qawäid al-Fiqhiyyah I \& II, Sociology of Islamic law, Muqāranat Qawäid al-Aḅeām, Islamic law in Indonesia, and contemporary Islamic thinking I \& II. Meanwhile, the secondary courses include the history of Islamic civilization I \& II, the history of Islamic thinking I \& II, the development of Modern thinking in Islam, Abl al-Sunnah wa'-Jamā'ah, Islamic mysticism I, II \& III, and Islamic philosophy. In addition, the supplemental courses include a thesis, the development of Islam in the West, Sociology, and Methodology of Islamic studies.

The core courses are based on books, which are usually read by a lecturer of Ma'ad Aly, or books which have to be referenced (al-kutub almuqarrarab) by the student in the writing of a paper as outlined in class discussion for core or secondary courses. Those books can be classified depending on the subject of knowledge. First, fiqh, covers the kitäb of Tabrir Tanqỉh al-Lubab, Fatḥ al-Mu in, Minhaj al-Ṭalibin, al-Mubadhdhab, I'anat al-Tälibin, Fatḥ al-Wahbāb bi-Sharh Minhaj al-Ṭulāb, al-Fiqh 'alā al-Madhāhib al-Arba'ah, Tubfat al-Mubtäj, Fiqh al-Sunnah, Bidāyat al-Mujtabid, and Nihāyat al-Mubtaj. Second, Usul al-Fiqh, includes the kitäb of 'Ilm Ușul al-Fiqh (by Khallāf), Usul al-Fiqh (by Abū Zahrah), Jam'ul Jawāmi', al-Mustasfā min Ilm al-Ușūl, al-Muwāfaqāt fi Ușül al-Aḥkām, al-Risalah, Rawdat al-Nāạir wa-Jannat al-Munāąir, al-I'tișàm, Ușul al-Fiqh al-Islami, al-Mahșül fi $\mathrm{Tlm}$ al- 


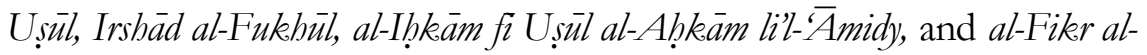
Usüli. Third, Qawäid al-Fiqh, includes the kitäb of al-Ashbah wa'-Nază'ir li'-Suyūti, al-Ashbah wa'-Naz̧äir li-Ibn Rajab al-Hanbali, al-Ashbab wa'lNaz̧äir li-Ibn Nujaym al-Hanifi, al-Ashbah wa'-Naz̧äir li'-Subkì, al-Qawäid al-Fiqhiyyah li-Ali Abmad al-Nadwi, and Athar al-Ikhtilaf fi al-Qawäid alUsüliyyah fi Ikbtiläf al-Fuqahä. Fourth, Ulüm al-Tafsir, Tafsir Aḅkàm, and Ulum al-Qur'an, includes the kitäb of Rawa'i' al-Bayan, Aḅkäm al-Qur'an lil-Jașsās, Aḅkeàm al-Qur'ān li-Ibn 'Arabi, al-Maräghi, al-jāmi' li-Aḥkām alQur'ān, Zubdat al-Itqān, Tafsì Ibn Katbir, al-Itqān fi 'Ulüm al-Qur'ān, Mabāàin al-Ta'wil, Rūh al-Ma'äni fi Tafsir al-Qur'àn al-Ažim wa'-Sab'i al-Mathäni. Fifth, Hadith, Ulum al-Hadith, and Hadith Aḅkam, includes kitäb of al-

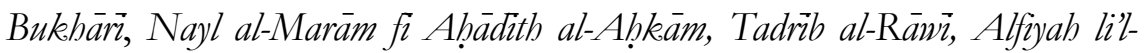
Suyuti, and Fath al-Bäri. Sixth, ethics and Islamic mysticism, includes the

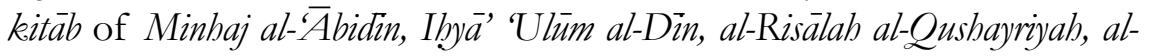
Luma' li'-Sarräj, al-Ta'arruf li-Madhbab Abl al-Tasawnuf li'-Kaläbädhi, alMunqid mina'-Ḍaläl li'-Ghazăhi, and Fusüs al-Hikam li-Mubyiddin Ibn 'A rabi. Seventh, beliefs ('Aqidah), includes kitäb of al-Ibānah 'an Ușül al-Diyanah and Ușül al-Din. Eighth, history (Tärikh), includes the kitäb of Tärikh alTashri' al-Islämi, Tärikh al-Tamaddun al-Islämi, Itmām al-Wafä' fi Sirat alKhulafä, and Tärikh al-Khulafä.

Lecturers in this institution are classified into four categories. First, guest lecturers which are called al-mashäikh. These lecturers are targeted to teach in Ma'had Aly, one meeting in one semester or at least one meeting in one year. Al-mashäyikh are KH MA Sahal Mahfudh, Prof. KH. Alie Yafie, KH Maimun Zubair, KH Abdurrahman Wahid, Prof. Dr. Quraisy Syihab, MA, KH. Muhammad Thalhah Hasan, KH Dr. Abdul Muhith Abdul Fattah, Dr. KH. Noer Iskandar al-Barsany, M.A, KH Ma'ruf Amin, KH. Drs. Malik Madani, MA., and KH. M. Tijani Jauhari, M.A.

Second, there are monthly lecturers, called al-asatidhah, who are expected to teach once a month or at least once in three months. They are KH Drs. Masdar Farid Mas'udi, MA., Prof. Dr. Said Aqiel alMunawwar, M.A, Prof. Dr.KH. Sa'id Aqiel Siradj, M.A, Prof. Soetandyo, KH. Drs. Nadhir Muhammad, MA., KH. Drs. Yusuf Muhammad, M.A, and KH. Drs. Muhyiddin Suwondo, MA. 
Third, are weekly (regular) lecturers. These lecturers are expected to give lectures once a week or at least once in one month. These lecturers include Prof. Dr. Sjeich Hadi Permono, SH., KH. Abdul Muchith Muzadi, KH. Drs. Afifuddin Muhajir, MA, KH. Drs. M. Hasan Basri, L.c, KH. Dailami Ahmad, KH Abdullah Muchtar, Lc., KH Hariri Abd Adhim, KH Ma'sum Syafi'ie, KH Dhafir Jazuli, KH. Drs. Salwa Arifin, Habib Hasan Baharun, Dr. Drs. Wawan Juandi, MA., Drs. H. Abu Yazid, MA, LLM, and KH. Drs. Hasyim Abbas.

Fourth, are assistant lecturers or mushrif. All of the assistant lecturers must regularly facilitate the informal discussion in Ma'had Aly. These lecturers are the best graduates of Ma'had Aly such as Ach. Muhyiddin Chotib, Drs. Imam Nacha'ie, M.Ag, and Dedy Wahyuddin, S.Ag.

Observing the method of teaching in Ma'had Aly, it is clear that Ma'had Aly provides several kitab kunings. By focusing on ușul fiqh, the student of Ma'had Aly has the capability to re-interpret the Qur'an and the hadith in order to make a new rule of figh (ijtih $\bar{a} d$ ) which is compatible with current conditions. In addition, the students know the many views found in the many kitab kunings which are read. Therefore, the different understandings of Islam found among kitab kunings lead students to select certain views or events to re-interpret (contextualizing) the Qur'an, whether in a collective ijtibäd or personal ijtibäd. Moreover, the lecturers of Ma'had Aly are well known as liberal and progressive, promoting freedom of thinking. The regular lecturers and assistants like $\mathrm{KH}$. Afifuddin Muhajir and Imam Nacha'ie are well-known as liberal Muslim thinkers.

\section{Method of Teaching}

The method of teaching in Mahad Aly starts from the basic ability to carry out the duties of scholarship, education, guidance, and elucidation in Muslim society, for the purpose of mastering academic ability (tafaqquh fil-din) and professional ability (takhasssus) in the plural society.

There are several methods of teaching in this institution. (1) Speech and dialogue. The lecturer gives his main thoughts depending on the syllabus, and then there is a dialogue between students and lecturer. (2) The method of tadris wa-ta'Tim. This method is used for manuscript studies. All students regularly read paragraphs of the kitäb and the lecturer 
gives the meaning and explanation of the text read. (3) Method of giving an assignment individually or collectively. Students must write a paper on themes chosen by the lecturer. This paper, then, is discussed in the class through the facilitation of the lecturer. (4) Method of mubadarah 'ammah (studium general) which is usually given by al-mashayikh on a certain topic. In this mubadarah 'ammah, it is not only followed by the students of Ma'ad Aly but also the lecturer of Institute of Islamic Studies of Ibrahimy (IAII) and regular lecturer of Ma'had Aly.

Besides that, the students have extra-curricular studies outside the class. There are three kinds: (1) mudhäkarah (mubähathah) or discussing on Fath al-Wahbäb (Fiqh) and Jam'u al-Jawämi' (Usüll Fiqh). This is done three times in one week at 06.00-07.45. The mastery to these kitab kunings is a requirement for being a jurist (mutafaqqib). Although this is extracurricular, all students are expected to join. In the daily discussion, students are divided into two classes that are facilitated by an assistant lecturer; (2) Discussion about fiqh on contemporary problems, which is called masäil al-fiqbiyyah al-waqi iyyah. The contemporary problems relating to the fiqh usually come from outside the pesantren, such as the branch of NU Situbondo, PWNU East Java, RMI (Rabithah Ma'ahid Islamiyah), or even PBNU; (3) Study club which is formed independently by students. In the study club, students have the freedom to discuss everything. There are at least two kinds of study club: (a) Fokus Kajian Ushul Fiqh (Fokus), established in 1998, discusses the methodology of Islamic law as well as some contemporary scholars such Mahmoed Muhammad Thaha, Abdullahi Ahmed al-Na'im, Hasan Turabi, and Jamal al-Banna; and (b) Pusat Studi Agama dan Filsafat (Pusfa), established in 1998, carries out discussion relating to philosophical issues, either Islamic or Western. Through this study club, students become familiar with the ideas of non-Muslim intellectuals such as Mao, Karl Marx, Max Weber, Durkheim, Nietzsche, etc. To expand and develop the discussion, this study club sometimes invites experts from outside the pesantren.

The method of teaching in Ma'had Aly liberates students to discuss everything, showing that there is no single understanding on Islam, because of different interpretations. It proves that students of Ma'had Aly are experiencing freedom of thinking that differs from other pesantrens which usually give limits to thinking. 


\section{Bulletin of Tanwirul Afkar}

Tanwirul Afkar [TA] is a weekly bulletin published by santri of Ma'had Aly Sukorejo, that contains elaborations of figh interacting with religious and social problems. Every week TA presents an actual problem and proposes figh as an approach to resolving the problem. TA is evidence of how the pesantren is able to pose solutions for social problems. To know how this bulletin appreciates reason, we can see several themes published. ${ }^{18}$

Interfaith marriage is no problem. Even though in classical texts the prohibition of interfaith-married is found, Machad Aly has a different interpretation. They state that surely a Muslim may get married to a non-Muslim. They cite some opinions from contemporary ulama, like Yusuf Qardlawi, who allow Muslims to have relationships with others. The prohibition of interfaith-marriage, for Ma'had Aly, is a product of a certain history. In the Muhammad era, being religious also indicated an affiliation to one group. Under that crucial condition, people cannot convert to other religions because they will be considered as murtad. Murtad sociologically means being a defector. Muhammad was in the process of building a strong community to fight against oppression in Arab. Therefore, Muhammad forbids Muslims to get married to people from other religions because it will demolish their faith. For our time, the condition is different. Muslims can get married to people from other religions without hesitation because other religions have the same goal as Islam.

Non-Muslim as the Indonesian President. The most problematic of TA's edition is the theme of the possibility of a nonMuslim being president. This issue is not only problematic in an Islamic context but also in Indonesia, which for a long time has had Muslim presidents. In every classical text, like fiqh of Abu Ya'la al-Fara' and alMaududi, Islam is required as an important element for the candidacy of a leader. Yet, Ma'had Aly contends that the requirement is only for Islamic countries. Why is Islam an important requirement for a leader? It is not surprising because Islam has a holistic-integrative view which

${ }^{18}$ LKiS book publisher has published most of those themes of bulletins, entitled Fikih Rakyat: Pertautan Fikih dan Kekuasaan (Yogyakarta: LKiS, 2000). 
never divides everything into religious and secular matters. Consequently, a leader in Islam, like Muhammad, holds two functions as a religious and government leader. For this consideration, the requirement is relevant in that context. However, in Indonesia, the requirement must be changed because Indonesia is not an Islamic country. The President only manages and focuses on secular matters. If being Muslim becomes a requirement of leader, it will negate and discriminate against other religions. Without hesitation, TA asserts that it is not impossible for a non-Muslim to be president. Indeed, in Islam, an essential requirement of a leader is the ability to secure justice and lead the state toward prosperity.

Jesus (Christianity) and Muhammad (Islam) in Dialogue. The title above is a metaphor of the relationship between Islam and Christianity. What the santri of Ma'had Aly mean by the title is to discuss the relationship between Islam and Christian from the perspective of figh. In classic figh, the position of other religions is problematic. Some ulama consider other religions as kafir (infidel) and that their followers must be converted into Islam. In their opinion, Islam is divined as the last religion that functions to complete others. Therefore, the presence of other religions was abrogated when Islam came.

By quoting many verses of the Qur'an, santri of Ma'had Aly, in their bulletin, asserts that Islam guarantees the existence of other religions. Qur'an: Al-Mā'idah, 5:48, states that diversity is willed by God. Every community has been sent a messenger by God. Furthermore, the santri explain that there is a close similarity between Christianity and Islam, in that both are derived from one tradition, the Abrahamic religion, monotheistic and descendents of Adam. Islam and Christianity are tied together as one brother to another brother of Arahamic religion, or brothers in humanity as descendents of Adam. The Qur'an, as the bulletin expounds, in verse of al-Baqara 62, states that all religions either Christianity, or Judaism, or Zoroastrianism, will give rewards from their God. This verse implies an understanding that Islam doesn't only appreciate the presence of other religion, but also acknowledges the truth of others. Further, in verse al-Maidah 82, the Qur'an notes that the closest friend of Islam actually is Christianity (Nasara is the Islamic term for Christianity). 
In short, the bulletin concludes that the relationship between Islam and Christianity should be continuously maintained in a tone of peacefulness. There is no reason to see them as essentially different. Both of them are the same, in either a theological or historical perspective. Such explanations are never found in classic texts. However, santri Ma'had Aly doesn't only deconstruct the traditional view of figh, but also tries to create a new one.

Women as leader. The role of women in the public sphere is still problematic. For some ulama, who negate the wider role of women, contend that women are weaker than men in some aspects. This opinion is drawn from one popular badith (a saying of the prophet that Muslims recognize as a second source of religion after Qur'an) narrated by alBukhārì (one of the six popular narrators of hadith) i.e. success will not be possible for a nation that is led by a woman. This hadith is most familiar with some ulama who reject the role of women in the public domain.

Historically, in that time, women were restricted in social life because the most prestigious role in that era was the ability to fight in war. The tradition of war makes women into secondary people and the inability of women to fight in war creates an image of women as weaker. To some extent, women also cannot attain more access in a social aspect. Therefore, some classical texts conceived women as weak beings who are not suitable for participating in the public sphere.

Conversely, Ma'had Aly proposes to see the nature of women in a new perspective. Indeed, Islam is a caring religion for women. The emergence of Islam deconstructs the oppressive structure by positing woman as equal to man. However, the struggle of Islam to advocate for women is a gradual action. For this reason, we are reminded that the gift of Islam to women in a certain context must be interpreted as a process to make man and woman equal.

The problematic hadith above must be understood as a product of history, in a certain context, that cannot be extended to any other particular context. In recent times, there is no reason to forbid women to be leaders. In qawa'id al-fiqh (the formula of fiqh), "a law will change because a change of context". In this sense, a law is a product of context. When the context is different, there will be differences of law. The belief 
that women cannot be leaders reflects the condition in a certain context in Arabic culture, but it is not applicable to some contexts like Indonesia. In short, there is no problem for women to be a leader.

The themes above illustrate that students of Ma'had Aly are brave to re-interpret and contextualize the Qur'an, badith, and kitab kuning. Because of this, some people sometimes judge that Ma'had Aly is liberal in the sense which Nahdlatul Ulama and Indonesia Ulama council (MUI) claim liberal as a deviation of Islam. The interpretation of Ma'ahad Aly is quite different from classical texts that impose the content of the text on the context. In this sense, context must follow what the text says. On the contrary, Ma'had Aly changes that logic by placing context as determinant for texts. For Ma'had Aly, truth is not fixed and stagnant because it always changes as far as circumstances change. This principle becomes a base for Ma'had Aly to search continuously for new truth and negotiate with contested meaning. In this sense, what we know and believe depends on context. When the context changes, the content of what we believe probably changes. Therefore, we cannot fully trust what we know or believe. For this reason, classical texts should be regarded for comparison not determining Islamic law.

\section{E. Concluding Remarks}

Observing the curriculum, the method of teaching and the bulletin of Tanwirul Afkar, proves that Ma'had Aly promotes freedom of thinking. The curriculum used in this pesantren enables santris to think without restraint, because the various kitab kunings used, lead the santris to understand the differences of thought among Muslim scholars. The access to classic and contemporary kitab kunings elucidate the development of Islamic studies, which finally go out from dogmatism (taqdis al-afkēr al-diniyah). Moreover, Ma'had Aly focuses on the methodology of fiqh (usiul fiqh), rather than its products (fiqh), giving the space to think liberally based on the local situation. In Usül al-Fiqh, reason (al-'aqd) has a special position for interpreting the source of law (alQur'an and hadith), contextualize and change the previous laws codified by Muslim scholars. Furthermore, teachers (ustädh, kiai) in Ma'had Aly also have a liberal understanding of Islam. Different from Liberal Muslim activists who have no deep roots in Islamic studies, these teachers 
precisely base their thinking on the kitab kunings, which are often claimed to be out of date.

The various resources used in Ma'had Aly are more powerful when the method of teaching supports the creation of an atmosphere of freedom of thinking. The method of teaching emphasizing discussion allows santris to understand deeper, contextualize and criticize kitab kunings. This differs from the common method of teaching in several other pesantrens which still use bandongan and sorogan in which santri have less space to ask, think and criticize, or know well the banking system. In Ma'had Aly, the student is not a blank cassette that is the teachers' duty to fill.

Due to the curriculum and method of teaching, we can see the freedom and liberal thinking in the weekly bulletin of Tanwirul Afkar. The themes of this bulletin are not out of date issues, but contemporary ones. This is important to say because several publications in other pesantrens are frequently confined to old-fashioned issues. By isținbät alaḅkam shown in this bulletin, Ma'had Aly is brave enough to leave conventional laws of Muslim scholar. Therefore, this Ma'had Aly, I think, is liberal and unique, different from other pesantrens which usually bind reason and thinking. Last but not least, by observing Ma'had Aly, the claim that the pesantren is a conservative and backward institution, to some extent, is misleading.

It is important to further make some notes. Firstly, we have to recognize the complexity of problems which cannot be solved by one perspective or approach. $u s \bar{u} l$ al-fiqh or fiqh is one perspective in approaching social problems. There are numerous approaches, which are important to know by santris in order to "sound" the Islamic law in society. The position of figh up to now only provides and judges " halalharam" issues, while the problem of how to solve the social problems or phenomena is untouchable. This is crucial, because the final purpose of Islamic law is not only providing judgment of "balal-haram", but also problem-solving. Finally, Islamic law must be oriented to problemsolving, which requires multiple perspectives.

Secondly, Ma'had Aly is well-known as a liberal institution. As we see in its bulletin, the interpretation of the text by Ma'had Aly is no longer literal, but contextual and based on the concept of maslahah. 
This kind of interpretation surely differs from the model of "terrorists" and/or "fundamentalists" which stress the literal meaning of the text. Therefore, Ma'had Aly is in some way against terrorism. However, I was shocked when I went to Ma'had Aly in 2006 about one santri, whose name is Imtihan, a graduate of Pesantren al-Mukmin, Ngruki. Although he studied at Ma'had Aly, he has a different understanding from most of the santris. He was denying coming to graves (zijarah), and, to some extent, interpreted the text literally. The acceptance into Mahad Aly of santri having a different ideology from NU causes two issues. (1) The inclusive character of Mahad Aly in accepting santri from any ideology, including alumni of al-Mukmin Ngruki, and (2) The image of this pesantren as a liberal institution will shift to being a "fundamentalist" institution. Therefore, Ma'had Aly, I think, has to take a clear position whether it becomes inclusive or fundamentalist.

Thirdly, the problem of Ma'had Aly is how to promote its thought to other pesantrens, because the leader of the pesantren is the kiai who has great power. In this context, Ma'had Aly should be brave and not only criticize the Qur'an but also the kiai (KH. Fawaid As'ad) in terms of his thoughts on Islam. It is important, because the failure or success of the pesantren to promote its thought depends on the kiai. 


\section{BIBLIOGRAPHY}

Abasri, "Sejarah dan Dinamika Lembaga-lembaga Pendidikan Islam di Nusantara: Surau, Meunasah, Pesantren, dan Madrasah", in Samsul Nizar (ed.), Sejarah Pendidikan Islam: Menelusuri Jejak Sejarah Pendidikan Islam Era Rasulullah sampai Indonesia, Jakarta: Prenada Media Group, 2007.

Al-Razi, Fakhruddin, Mafätḥ al-Ghayb, Beirut: Dār al-Fikr, 1993.

Anwar, M. Syafi'I, "Uncovering the Wisdom of Pesantren for Multiculturalism", ICIP Journal, Vol 4, no. 1, June 2007.

van Bruinessen, Martin, "Pesantren and Kitab Kuning: Maintenance and Continuation of a Tradition of Religious Learning", in Wolfgang Marschall (ed.), Texts from the Islands. Oral and Written Traditions of Indonesia and the Malay World, Berne: University of Berne, 1994.

- Kitab Kuning, Pesantren, dan Tarekat: Tradisi-tradisi Islam di Indonesia, Bandung: Mizan, 1999.

Dhofier, Zamakhsyari, Tradisi Pesantren: Studi tentang Pandangan Hidup Kyai, Jakarta: LP3ES, 1982.

Rushd, Ibn, Fașl al-Maqäl fi Taqrir mā bayn'-Sharīáh wa'l-Hikmah mina'lIttișäl, Beirut: Markaz Dirāsat al-Wiḥdah al-'Arabiyah, 1999.

Tibi, Bassam, Ancaman Fundamentalisme, Rajutan Islam Politik dan Kekacauan Dunia Baru, trans. Imron Rosyidi, dkk, Yogyakarta: Tiara Wacana, 2000.

Tim Penulis Sejarah Pesantren, Pedoman Santri Baru Pesantren Salafiyah Syafi'iyah Sukorejo Situbondo, Situbondo: As-syarif Press, 1999.

Tim Redaksi Santri Ma'had Aly, Fiqh Rakyat: Pertautan Fiqh dengan Kekuasaan, Yogyakarta : LKiS, 2000.

Wahib, Ahmad, Pergolakan Pemikiran Muslim, Jakarta: LP3ES, 2003.

Wahid, Marzuki, "Ma'had Aly; Nestapa Tradisionalisme dari Tradisi Akademik yang Hilang", Istiqro: Jurnal Penelitian Islam Indonesia, Volume 04. Nomor 01, 2005. 